\title{
透析患者の sexual potency と下垂体・性腺機能
}

\author{
川西泰夫今川章夫 \\ 高松赤十字病院泌尿器科
}

(昭和 59 年 7 月 30 日受付)

key words：透析患者, 下垂体一性腺機能，性機能，AVSS

〈要旨〉

尿毒症から回復し安定期にはいった透析患者にとって性生活は重要な問題であるが, 本邦では性をタブー視する傾 向にあり，十分な対応ができていないのが実情である.IMP の客観的評価について，勃起現象の記録が必要条件であ ると考え, 性的刺激に対する陰茎の变化を測定し, 下垂体・性腺系の機能との相関を検討した。週 3 回の外来透析を 受けている男子腎不全患者（25-64 歳）8例に性機能検査を行い勃起能力について検討を行った。同時に，末梢血の testosteron, LH, FSH, PRL, serotonin, 亜鉛を測定し, 陰茎の変化と相関があるかどうか検討した。性機能検査の方 法は視聴覚的性刺激 (audiovisual sexual stimulation, AVSS) に対する陰茎の変化と, 刺激を定量化するための生体 の反応 (脳波, 血圧, 脈拍数, galvanic skin reflex (GSR), 呼吸波, 海綿体筋筋電図) との同時測定を行い, sexual stimulation score (SSS) を求めた。本法は陰茎の変化, 刺激の程度の定量性があり, しかも外来検査が可能であり, 透析患者に対する検査としてはNPT よりも適切である. 陰茎の変化はほぼ正常と考えられたものが 2 例, わずかな 反応を示したもの 3 例, 無反応 3 例であったが, tumescence の程度は年齢や透析期間と一定の傾向は認められない. testosteron, LH, FSH, PRL, serotonin, 亜鉛と陰茎の変化は相関はなく, 透析患者の性機能と精腺機能不全および亜 鉛欠乏とは関係がないことが明らかとなった。透析により除去されない物質や，不足する物質による臓器の反応性の 低下が本態であると考えられる。当面はIMP 症例の個別的な原因を明らかにし，光の集積から解明の糸口を発見する 努力が必要と思われる.

\section{Sexual potency and pituitary-gonadal axis in hemodialysed patients}

Yasuo Kawanishi, M. D., and Akio Imagawa, M. D.

Department of Urology, Takamatsu Red Cross Hospital, Kagawa

For patients on maintenance hemodialysis, sexual life is a matter of great importance. In Japan, however, little recognition has been accorded to this concern. We believe it is important to record penile tumescence objectively in the diagnosis of impotence.

We investigated the correlation between penile tumescence and pituitary-gonadal function. The patients, aged 25 to 64 years, were male uremic patients who received hemodialysis 3 times per week. These patients, 8 in number, underwent examination for sexual function and pituitary-gonadal function.

The method for testing penile tumescence employed an audiovisual sexual stimulation test. We recorded EEG, blood pressure, pulse, Galvanic skin reflex, respiration wave, and bulbocavernous EMG for the purpouse of recognizing the level of stimulation. As this method is quantitative in the recording of tumescence and the mount of stimulation, no hospital admission is required.

In 2 cases the penile change could be considered normal, 3 cases showed slight reaction, and in 3 cases there was no reaction. The degree of tumescence showed no definite correlation with age or period of dialysis. The penile changes showed no correlation with testosterone, LH, FSH, PRL, serotonin or $\mathrm{Zn}$. It remained unclear whether

川西泰夫 高松赤十字病院泌尿器科

于760 高松市番町 4-1-3 (0878-31-7101) 
there was any relationship between $\mathrm{Zn}$ insufficiency and sexual function.

For the present, it is still necessary to make an effort to clarify the causes of impotence.

\section{緒言}

尿毒症から回復し安定期に入った透析患者は, 長期間 の闘病生活で失われた社会生活や家庭生活の修復に勤め る。現今の透析療法は，単に延命だけが目的でなく，患 者の個人的，社会的活動の量と質を保証しなければなら ない.

性生活も重要な問題で，中山 ${ }^{1)}$ は「透析患者にとって, 性機能は生命に次いで重大な関心事であり, 最も重要な チェックポイントの1つであると確信する」と述べてい る。しかし, 本邦では性をタブー視する傾向にあり, 患 者側からの訴えは意外に少なく，また医療の側も十分な 対応はできないのが実情である。

近年, 透析患者のインポテンス (IMP) について多く の報告があるが，ほとんど論文が性機能の検討は患者の 問診による手法を採用し，せっかく原因となる要因につ いて科学的検索がなされても勃起現象の把握が客観的で なく, 批判に耐えうる論文は少ない。

著者は IMP の客観的評価について，勃起現象の記録 が必要条件であると考え, 簡便な性機能検査法として, 性的刺激に対する陰茎の変化を測定し, 下垂体一性腺系 の機能との相関を検討したので報告する.

\section{対象・方法}

対象は週 3 回の外来透析を受けている男子腎不全患者 で, 年齢は 25 歳から 64 歳 (平均 53.1 歳), 透析導入後 29 力月から 53 力月 (平均 42.0 力月) で, 原疾患は慢性 腎炎 6 例, 腎硬化症 1 例, 囊胞腎 1 例の計 8 例である.
対象症例は 8 例とも既婚であり，問診で 3 例は満足の ゆく性生活が可能，1例は不十分ながらも可能，4例は 困難との回答を得た。

これら 8 例に性機能検查を行い勃起能力について検討 を行った。同時に,末梢血の testosteron, LH, FSH, PRL, serotonin, 亜鉛を測定し, 陰茎の変化と相関があるかど うか検討した。

性機能検查の方法は視聴覚的性刺激 (audio visual sexual stimulation, AVSS) に対する陰茎の変化と, 刺 激を定量化するための生体の反応 (脳波, 血圧, 脈拍数, galvanic skin reflex (GSR), 呼吸波, 海綿体筋筋電図) との同時測定を行った。陰茎の変化は mercury strain gauge による陰茎周の変化率 ( $\Delta$ tumescence\%) を測定 した。脳波は $\beta$ 波成分の割合を，呼吸は 1 分あたりの数 の変化と深さの変化を, GSR は $2 \%$ 以上変化した波の数 を計測した。血圧，脈拍数は自動血圧計を用いて 1 分ご とに計測して AVSS 負荷前後の平均值を比較した.

以上の項目のうち正常被験者にて $5 \%$ の危険率で陰茎 周変化率と相関関係のあった収縮期血圧，1\%の危険率 で相関のあった拡張期血圧, GSR, 呼吸数, 呼吸の深さに ついて 0 点から 3 点を与える sexual stimulation score (以下 SSS と略す) を作成し, SSS と陰茎の変化は正の 相関を示すことをすでに発表した。すなわち SSS が高い ほどAVSS の刺激が強く, 正常人では刺激に応じた陰茎 の変化が認められ, SSS に対して相応な陰茎周の変化を 示さない場合は勃起力が低下していると診断しうる。

\begin{tabular}{|c|c|c|c|c|c|c|c|c|c|c|c|}
\hline 症例 & 年齢 & $\begin{array}{c}\text { 透析期間 } \\
(\text { 月 })\end{array}$ & 原疾患 & $\Delta$ tumescence $\%$ & $\begin{array}{c}\text { 収縮期圧 } \\
(\Delta \%)\end{array}$ & $\begin{array}{c}\text { 拡張期圧 } \\
(\Delta \%)\end{array}$ & $\begin{array}{c}\text { GSR } \\
(\Delta)\end{array}$ & $\begin{array}{c}\text { 呼吸数 } \\
(\Delta)\end{array}$ & $\begin{array}{c}\text { 呼吸深度 } \\
(\Delta)\end{array}$ & SSS & $\Delta$ tumescence $\% /$ SSS \\
\hline \multirow[t]{2}{*}{1} & \multirow[t]{2}{*}{58} & \multirow[t]{2}{*}{29} & \multirow[t]{2}{*}{ 囊胞賢 } & 0 & 8.1 & 4.5 & 14 & 7 & 0 & 8 & 0 \\
\hline & & & & 0 & 6.7 & 5.7 & 4 & 3 & 2 & 5 & 0 \\
\hline \multirow[t]{2}{*}{2} & \multirow[t]{2}{*}{43} & \multirow[t]{2}{*}{49} & \multirow[t]{2}{*}{ 慢性腎炎 } & 8.4 & 21.0 & 13.2 & 6 & 7 & 0 & 9 & 0.93 \\
\hline & & & & 10.4 & 20.0 & 10.8 & 8 & 4 & 1 & 9 & 1.16 \\
\hline \multirow[t]{2}{*}{3} & \multirow[t]{2}{*}{54} & \multirow[t]{2}{*}{52} & \multirow[t]{2}{*}{ 慢性腎炎 } & 0 & 7.8 & 2.6 & 0 & 0 & 2 & 1 & 0 \\
\hline & & & & 0 & 0 & 0 & 0 & 1 & 4 & 1 & 0 \\
\hline \multirow[t]{2}{*}{4} & \multirow[t]{2}{*}{25} & \multirow[t]{2}{*}{37} & \multirow[t]{2}{*}{ 慢性腎炎 } & 54.3 & 13.0 & 8.5 & 1 & 7 & 8 & 9 & 6.03 \\
\hline & & & & 41.1 & 13.0 & 2.8 & 0 & 7 & 3 & 6 & 6.85 \\
\hline \multirow[t]{2}{*}{5} & \multirow[t]{2}{*}{62} & \multirow[t]{2}{*}{35} & \multirow[t]{2}{*}{ 慢性腎炎 } & 15.9 & 9.0 & 7.0 & 0 & 3 & 0 & 5 & 3.18 \\
\hline & & & & 29.7 & 15.0 & 10.0 & 0 & 2 & 0 & 6 & 4.95 \\
\hline \multirow[t]{2}{*}{6} & \multirow[t]{2}{*}{60} & \multirow[t]{2}{*}{29} & \multirow[t]{2}{*}{ 慢性腎炎 } & 7.7 & 9.0 & 0 & 3 & 1 & 2 & 2 & 3.85 \\
\hline & & & & 11.5 & 0 & 0 & 3 & 2 & 5 & 3 & 3.83 \\
\hline \multirow[t]{2}{*}{7} & \multirow[t]{2}{*}{64} & \multirow[t]{2}{*}{52} & \multirow[t]{2}{*}{ 腎硬化症 } & 0 & 6.0 & 7.0 & 2 & 3 & 4 & 9 & 0 \\
\hline & & & & 0 & 4.0 & 3.0 & 4 & 0 & 0 & 3 & 0 \\
\hline \multirow[t]{2}{*}{8} & \multirow[t]{2}{*}{59} & \multirow[t]{2}{*}{53} & \multirow[t]{2}{*}{ 慢性腎炎 } & 11.2 & 13.0 & 8.0 & 0 & 3 & 8 & 8 & 1.4 \\
\hline & & & & 5.6 & 9.0 & 6.0 & 0 & 0 & 6 & 4 & 1.4 \\
\hline
\end{tabular}




\section{結果}

結果を表 1 に示した。 $\Delta$ tumescence\%は 0 から $54.3 \%$ で，ほほ正常と考えられる $20 \%$ 以上の増加を示し たものが 2 例 $(25 \%)$ ，わずかな反応を示したもの 3 例 $(37.5 \%)$ ，無反応 3 例 $(37.5 \%)$ であった。

収縮期血圧の変化率は 0 から $15.0 \%(9.7 \pm 6.0)$, 拡張 期圧の変化率は 0 から $13.2 \%(5.5 \pm 4.0)$, GSR の増加 は 0 から $14 /$ 分 $(6.2 \pm 16.9)$, 呼吸数の変化は 0 から $7 /$ 分 $(3.1 \pm 2.6)$, 呼吸の深さの変化は深呼吸時 $20 \mathrm{~mm}$ に した条件で 0 から $8 \mathrm{~mm} \quad(2.8 \pm 2.79)$ であった。

SSS は 1 から 9 で, 有効な刺激と考えられる SSS が 3 以上は 16 回のうち 13 回 (81\%) で症例 3 に対して有 効な刺激を与えられなかった。

$\Delta$ tumescence\%/SSS 0 から 6.85 であるが, 正常は 症例 4 と症例 6 の 2 例のみであった。以上により今回の 8 例 16 回の検査で症例 4,6 が正常型であること, 症例

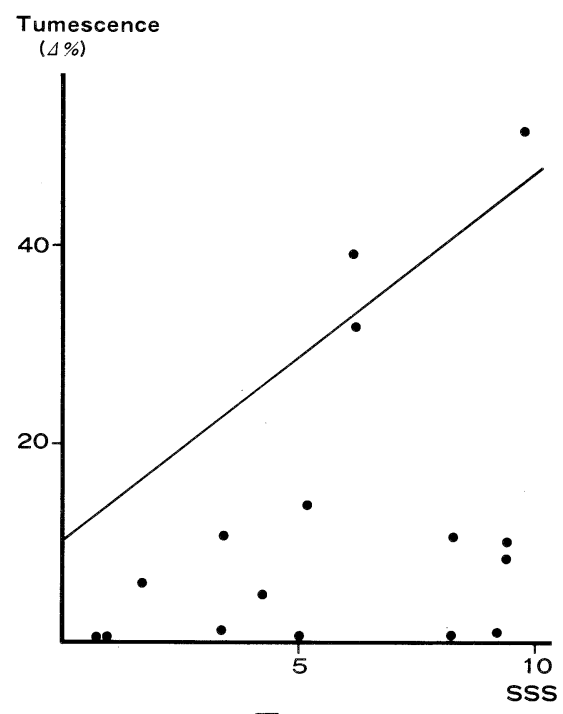

図 1
3 に対しては有効な刺激が与えられていないこと，症例 $2,7,8$ の勃起は不十分であること, 症例 1,5 は有 効な刺激に対してもまったく勃起が見られないことがわ かった（図 1 ).

また，血液検査の結果を表 2 に示した。 testosteron は

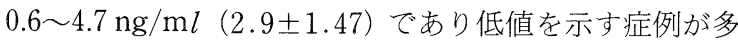
いが, 陰茎の変化率との間には一定の関係はみられな かった（図 2 )。

$\mathrm{LH}$ は $28.2 \sim 390 \mathrm{mIU} / \mathrm{m} l \quad(88.8 \pm 122.66)$ と高值を 示していた。陰茎の変化とは相関していない.

$\mathrm{FSH}$ は 4.9〜 $56.5 \mathrm{mIU} / \mathrm{ml} \quad(17.4 \pm 17.00)$, 陰茥の変 化とは相関は認められない。

$\mathrm{PRL}$ は $11.5 \sim 30.2 \mathrm{ng} / \mathrm{m} l \quad(20.1 \pm 5.61)$ で高值を示 す症例が多いが，陰茎の変化と相関はない.

serotonin は今回対象とした患者では $0.02 \sim 0.15 \mu \mathrm{g} /$ $\mathrm{m} l(0.07 \pm 0.049)$ と正常範囲であった. serotonin も 陰茥の変化率とは相関しない.

覀鉛は $69 \sim 90 \mu / \mathrm{d} l \quad(82.1 \pm 6.20)$ と正常範囲内にあ り，陰茎の変化とは相関関係をみいだせない.

\section{考察}

勃起現象の記録法は性的刺激に対する陰茎の変化を記 録する方法 ${ }^{2,3)}$ と rapid eye movement (REM) 睡眠相に 生理的に見られる夜間陰茥勃起現象 (nocturnal penile tumescence, NPT) を記録する方法4)がある。

NPT が IMP の鑑別診断に用いられるのは, 器質的 IMP では勃起が器質的変化により REM 睡眠相にも生 じないのに対し，機能的 IMP では睡眠中には精神的要

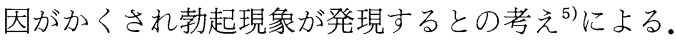

著者は IMP を訴える透析患者について NPT を検討 しすでに報告した 。勃起不全を訴える患者 8 名には NPT が認められず，勃起はするが満足した性生活が行 えないと訴える 4 名は NPT の回数と持続が低下してい た.したがって透析患者の IMP は器質的と考えられる。

しかし本法は入院が必要なこと, 特殊な設備がいるこ とにより普及が困難であるとともに透析患者では REM

\begin{tabular}{c|cccccc}
\hline 症例 & $\begin{array}{c}\mathrm{T} \\
(\mathrm{ng} / \mathrm{m} l)\end{array}$ & $\begin{array}{c}\mathrm{LH} \\
(\mathrm{mIU} / \mathrm{m} l)\end{array}$ & $\begin{array}{c}\mathrm{FSH} \\
(\mathrm{mIU} / \mathrm{m} l)\end{array}$ & $\begin{array}{c}\mathrm{PRL} \\
(\mathrm{ng} / \mathrm{m} l)\end{array}$ & $\begin{array}{c}\text { Ser } \\
(\mu \mathrm{g} / \mathrm{m} l)\end{array}$ & $\begin{array}{c}\mathrm{Zn} \\
(\mu \mathrm{g} / \mathrm{dl})\end{array}$ \\
\hline 1 & 3.6 & 47.7 & 9.2 & 11.5 & 0.02 & 80 \\
2 & 1.5 & 43.5 & 7.9 & 23.2 & 0.05 & 69 \\
3 & 0.6 & 28.2 & 6.9 & 30.2 & 0.15 & 83 \\
4 & 4.2 & 36.8 & 4.9 & 20.3 & 0.07 & 81 \\
5 & 3.3 & 74.9 & 24.2 & 17.0 & 0.03 & 90 \\
6 & 1.6 & 36.3 & 15.1 & 19.3 & 0.07 & 86 \\
7 & 4.71 & 52.5 & 14.6 & 23.1 & 0.14 & 83 \\
8 & 3.7 & 390.6 & 56.5 & 16.2 & 0.04 & 85 \\
\hline
\end{tabular}




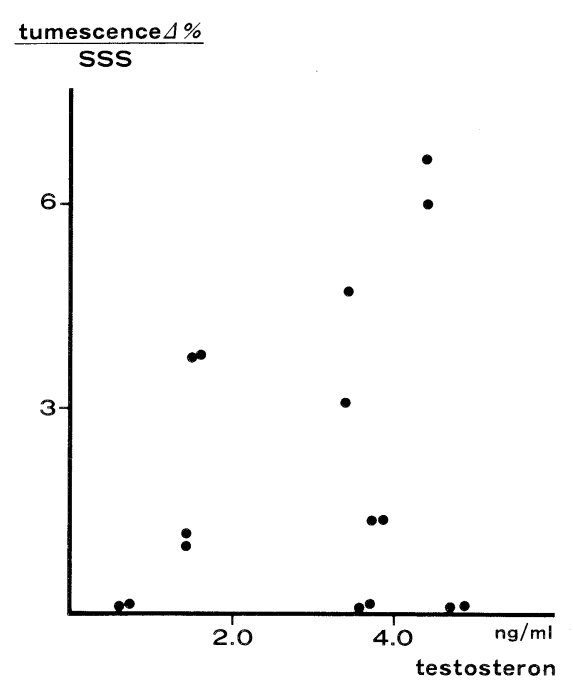

図 2 陰茎の変化-testosteron

睡眠が減少するなど問題点も多いので, 簡便な勃起の記 録法の開発がまたれた。

AVSS は性的視覚刺激に対する陰茎の変化を記録す る方法であるが，陰茎の変化を皮虐温の変化などで記録 していたため，定量性がないことと，刺激が定量的でな いことに欠点があった。この欠点に対し，前者について は水銀ストレインゲージを使用することにより定量性を 持たせ，後者についてはポリグラフィの同時測定による SSS 導入により欠点を克服した。また本法では外来検査 が可能であり，透析患者に対する検査としては NPTょ りも適切である。

さて, 男性腎不全患者では 36\%から $87 \%$ が性機能障害 を持ち，11\%から 55\%が IMP である7-17) とされている. また透析患者の IMP の原因は，1）精神的抑圧や不安, 2) 腎不全による体力の低下，3）神経障害，4）血管 障害，5）内分泌障害，6）薬物，7）脳幹機能障害, 8 ）亚鉛欠乏などが報告されている。これらのうち性機 能格検查が科学的に行われたものは, 自律神経障害 ${ }^{18)}$, 亜 鉛 ${ }^{19)}$, 脳幹機能障害 ${ }^{20)}$ などであり, 透析患者に多くみら れ, 性機能と強く関係すると抢もわれる下垂体一性腺機 能不全との相関についえては検討されていない.

透析患者では血清テストステロン值が低く, 血清 LH 值が高く, 血清 FSH 值が正常の傾向 ${ }^{13,17,21)}$ であるが, AVSS で検討したところ, 性機能と性腺機能不全とは相 関がないことが明らかとなった。

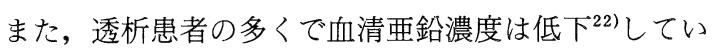
ること，覀鉛の欠乏は性腺不全を来すこと ${ }^{23)}$ より透析患 者の IMP は亜鉛が関与しているとの報告があるが，今 回の結果は透析患者の IMP は亜鉛欠乏と関係がないこ

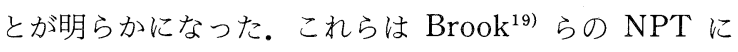
よる検討を支持するものである。

著者は透析患者の IMP の多くの可逆性の器質的原因 によると想定している.透析により除去されない物質や， 不足する物質による勃起に関与する臟器の反応性の低下 が本態であると考えられる。したがって，可逆性の因子 を同定し治療することが望ましいが，当面は IMP 症例 の個別的な原因を明らかにし，その集積から解明の系口 を発見する努力が必要と思われる。

\section{まとめ}

インポテンスは社会復帰した透析患者の重要な問題で あるが，診断法，原因，治療法などについては未解決の 問題が多い。今回報告したAVSS は, NPT に比べ手技 的に妥当であり透析患者の性機能検查には欠かせない検 査法と考えられ，透析患者にみられる下垂体一性腺系の 異常や亜鉛と性機能との間には相関は認められなかっ た。

\section{文献}

1) 中山 健：慢性血液透析患者の男性性腺機能不全. 西日泌尿，42：565-572，1980.

2）白井将文：男性インポテンスに関する研究。第一報 I 132 (人血清アルブミン) 使用による器質的インポ テンスと機能的インポテンスとの鑑別診断に関する 研究. 日泌尿会誌, 62:147-155, 1971.

3）越戸克和, 酒徳治三郎：インポテンス診断に対する サーモグラフィーの応用. Sexual Medicine, 3 (12) : 28-35, 1976.

4）前林浩次, 野田益弘：勃起不全の診断, 第 1 報 REM (rapid eye movement) 睡眠時勃起現象の臨床応用 について. 日泌尿会誌, 71:1384-1389, 1980.

5) Karacan, I. : Clinical value of nocturnal erection in the prognosis and diagnos is of impotence, Med. Aspects Hum. Sex., 4 : 27-34, 1970.

6）今川章夫, 米澤正隆, 赤澤誠二, 真弓研介: 勃起不 全を訴える透析患者の REM (rapid eye movement）睡眠時の勃起現象について。日腎誌，24： 1173-1180, 1982.

7) Levy, N. B., Sexual ajustment of maintenance hemodialysis and renal transplantation. Transcrp. Soc. Artf. Intern. Organs, 19 : 138-143, 1973.

8) Thurn, J.: Sexual potency of patients on hemodialysis. Urology, $5: 60-62,1975$.

9) Sherman, F. B. : Impotence in patients with chronic renal failure on dialysis. Frequency and etiology, Fertil. Steril., 26 : 221-223, 1975. 
10) Abram, H. S., Hester, L. R., Sheridan, W. F. and Epstein, G. M. : Sexual function in patients with chronic renal failure. J. Nerv. Ment. Dis., $160: 220$ $-226,1975$.

11) Bommer, J., Tschope, W., Ritz, E. and Andrassy, K. : Sexual behavior of hemodialized patients. Clin. Nephrol, $6: 315-318,1976$.

12) Steele, T. E., Finkelstein, S. H. and Finkelstein, F. O. : Hemodialysis patients and spouses. Marital discord, sexual problems and depression, J. Nerv. ment. Dis., 162 : 225-237, 1976.

13）澤西謙次，川村寿一，大迫文磨：腎不全と性機能. 腎と透析，5：208-214，1978.

14) Milne, J. F., Golden, J. S. and Fibus, L. : Sexual dysfunction in renal failure: A survey of chronic hemodialysis patients. Int. J. Psychiatry Med., 8 : 335-345, 1977-78.

15) Kaplan De-nour, A. : Hemodialysis : Sexual functioning. Psychosomatics, 19 : 229-235, 1978.

16) Levy, N. B.: The sexual rehabilitation of the hemodialysis patient. Sexuality and Disability, $2: 60-65,1979$.
17）赤枝輝明：慢性透析患者におけるインポテンスに関 する研究. 日泌尿会誌, 73：189-205, 1982.

18) Campese, V.M., Procci, W.R., Levitan, D., Romoff, M. S. : Autonomic nervous dysfunction and impotence in uremia. Am. J. Nephrol., $2: 140$ $-143,1982$.

19) Brook, A. C., Johnston. D. G., Ward, M. K., Watson, M. J ; Absence of therapeutic effect of zinc is the sexual dysfunction of hemodialysed patients, Lancet, 2 : 618-620, 1980.

20）滝川 浩, 湯浅 誠, 前林浩次, 今川章夫：透析患 者の性機能と間脳・下垂体・脳幹機能. 人工透析研 究会会誌, $11 ： 351-352,1978$.

21）Chen, J. C., Vidt, D. G., Zorn, E. M., Hallberg, M. C. : Pituitary-leydig cell function in uremic males. J. Clin. Endocr., 31 : 14-17, 1970.

22) Ellis, L.: Serum zinc levels and urinary zinc excretion in patients with renal transplants. Clinca. Chimica. Acta., 82 : 105-111, 1978.

23) Lei, K. Y., Abbasi, A. and Prasad, A. S. : Function of pituitary-gonadal axis in zinc-defecient rats. Am. J. Physiol, 230 : 1730-1732, 1976. 